\title{
Bioremediation of Heavy Metals in
}

\section{Contaminated Soil from Abandoned Asa Dam Road Dumpsite}

\author{
Abdus-Salam Nasiru ${ }^{1}$, Ademola Olamide Sodiq ${ }^{1,2}$, Oyewumi-Musa Rukayat Titilayo ${ }^{3}$
}

\author{
${ }^{1}$ Department of Chemistry, University of Ilorin, P.M.B. 1515, Ilorin, Kwara State, Nigeria \\ ${ }^{1}$ Email: nasalami2002@yahoo.co.uk Telno: +2348033950752 \\ ${ }^{2}$ Email: Horlardiamond@yahoo.co.uk Tel. no: +2348053115015 \\ ${ }^{3}$ Department of Chemistry, Al-Hikmah University, P.M.B. 1016, Ilorin, Kwara State, Nigeria \\ ${ }^{3}$ Email: titilayomusa@gmail.com $\quad$ Tel. no: +2348038083240
}

\begin{abstract}
The dispersion pattern of heavy metals in soils surrounding municipal solid waste dumps was studied in a major area at Asa Dam Road, Ilorin, Kwara State. Soil samples were collected at three depths i.e.,0-15, 15-30 and 30-45 cm. The bioremediation capacity of five plants (Amaranthushybridus, Celosia agentea, Tithoniadiversifolia, Manihotescunlenta, Ipomeabatatas) grown on the dumpsite were studied for different metals. The moisture contents of the soil samples and plants were $4.55-18.58 \%$ and $3.75-13.78 \%$ respectively. The $\mathrm{pH}$ of soil and plants ash contents was in the range of $6.7-7.5$ and 6.35 - 21.0 respectively. Atomic Absorption Spectroscopy method was employed in the determination of the concentration of $\mathrm{Fe}, \mathrm{Ca}, \mathrm{Mg}, \mathrm{Zn}, \mathrm{Cd}, \mathrm{Ca}$ and $\mathrm{Pb}$ in both plant and soil samples. Amaranthushybridus and Celosia agentea were found to hyper-bioaccumulate, Tithoniadiversifoliabioaccumulate heavy metals mildly while Manihotescunlenta hyper-accumulate Iron. Cadmium and Lead were not detected in the plants. Nitrate concentration increases progressively down the soil profile and highest in Tithoniadiversifolia among the plants.
\end{abstract}

Keywords - Bioaccumulation, bioremediation,dumpsite, heavy metal, plants, soil.

\section{INTRODUCTION}

It has been realized over the years that man generates waste of all sorts from his daily activities at home (domestics), farms (agricultural), industries, streets etc. These consist of combustible, non-combustible, putrescible and non-putrescible wastes (Douglas, 2013). As the wastes are being generated, they need to be collected and disposed every day. Hence, the calls for waste dump sites at various locations at the outskirts of the town to avoid pollution of the land, air and water sources and also to prevent outbreaks of diseases. However, as the towns expand (urbanization), problems continue to evolve. The dumpsites become encircled by houses and have to be abandoned, while new sites are sought for. The growing population increases the volume of waste generated (Abdus-Salam, 2009) and the existing dump sites become too small.

As regards some of the heavy metals in the waste, unfortunately dump sites rather mobilize the metals in the waste and accelerate the release of the metals to the environment. The major pathway of heavy metals release from waste to the environment is leaching of metals from wastes (Duruibe et al., 2007). Once heavy metals get into the environment, whether in small or large quantities, they cannot be completely eliminated (Ogundiran and Osibanjo, 2008). Though, several metals are essential for biological systems and must be present in a certain concentration range, too low or too high concentration lead to a decrease in metabolic activity or toxicity in plants and animals respectively. Soil is a nonrenewable dynamic resource and acts as an interface between agriculture and the environment (Ajaz et al.,2010). Excess concentrations of heavy metals such as $\mathrm{Cd}^{2+}, \mathrm{Cr}^{4+}$, $\mathrm{Cu}^{2+}, \mathrm{Ni}^{2+}, \mathrm{Pb}^{2+}, \mathrm{Fe}^{2+}$ and $\mathrm{Zn}^{2+}$ in soil have caused the disruption of natural terrestrial ecosystems (GardeaTorresdey et al.,2001).

Toxic metals when present in our body are capable of causing serious health problems, by interfering with our normal body functions, while some are useful to the body in lowconcentrations such as copper, iron and nickel but are toxic at high concentrations (Scott, 1992). They disrupt bodily functions by accumulating in vital organs and glands in the human body such as in the heart, brain, kidney, bone and liver (Salami and Adekola, 2002). They also displace vital nutritional minerals from their physiological positions. Calcium displacement from a metalloenzyme by $\mathrm{Cd}$ or $\mathrm{Pb}$ brings about disruption of enzymic reactions. Heavy metals are known to cause genotoxicity as they affect the DNA and immune-toxicity 
as they are major irritants to the body (Scott, 1992). These negative consequences necessitate heavy metal remediation from pollution sites. A promising, relatively new technology for heavy metal removal from contaminated sites is bioremediation. The uptake and bioaccumulation of heavy metals in vegetables is influenced by many factors such as climate, atmospheric depositions, heavy metals concentration in soil, the nature of soil and the degree of maturity of the plants at the time of the harvest (Nwoko and Mgbeahuruike, 2011).

The objective of this study was to determine the level of heavy metals in the soil of an abandoned dump site at Asa Dam Road, Ilorin and the level of heavy metals that are hyper-accumulated in some plants, specifically planted on the polluted soil for the purpose of this research work. More so, to know which is the best plant species for bioremediation amongst sweet potato (Ipomeabatatas), tree marigold (Tithoniadiversifolia), amaranth (Amaranthushybridus), plumed cockscomb (Celosia agentea), cassava (Manihotesculenta) and maize (Zea mays).

\section{MATERIALS AND METHODS}

2.1 Dumpsite area:The area studied is the abandoned dump site opposite the Kwara State Metropolitan square along Asa Dam Road, Ilorin, Kwara State, Nigeria. The dump site existed for about 25 years covering 6 hectares of land space. It is a large sized dump sitecharacterized by municipal waste. As a result, surface run-offs contaminated with municipal wastes drain directly into the associated dump site soil.

2.2Sample collection:Nine soil samples were collected on the abandoned dump site and were used in this study. Three sampling points were chosen as described as site nearest to Asa Dam Road (Station 1), center (Station 2) and opposite station 1 but towards the end of the dump site (Station 3), starting from the road side. The soils were collected at $(0-15) \mathrm{cm},(15-30) \mathrm{cm}$ and $(30-45) \mathrm{cm}$ depth from the three stations, using hand auger and stored in a sealed polythene bag.

Five plants samples were obtained from the dumpsite to attain the objectives of this research work. The five plants samples are: Celosia agentea(plummed cockscomb), Manihotescunlenta(cassava), Tithoniadiversifolia(tree marigold), Amaranthushybridus(pig weed) andIpomeabatatas(sweet potatoes). At maturity (Amaranthushybridus and Celosia agentea 3 weeks; Tithoniadiversifolia 6 weeks; Ipomeabatatas and Zea mays 12 weeks; Manihotescunlenta 24 weeks), these plants were harvested and processed for heavy metal bioaccumulation.
2.3 Sample preparation: The plants samples were pretreated by physical removal of soil entangled to it and washed with distilled water. The plants samples were air dried in the laboratory for some days and then homogenized by grinding using a mortar and pestle.

2.4Determination of soil $\mathrm{pH}$ :The $\mathrm{pH}$ of soil samples were determined following method described by Schofield and Taylor, (1955). A $15 \mathrm{~g}$ of the soil sample was weighed into a $50 \mathrm{ml}$ beaker with a graduated scoop. A $30 \mathrm{ml}$ of $0.01 \mathrm{M} \mathrm{CaCl}_{2}$ was added and stirred into suspension. It was stirred again after 15-20 minutes and allowed to stand for $30 \mathrm{~min}$ to allow sediment to settle. A calibrated $\mathrm{pH}$ meter was immersed into the partly settled suspension and the $\mathrm{pH}$ was recorded when the reading stabilized.

2.5 Plants moisture content determination:The moisture content of plant samples were determined following method described by UCDAVIS, (2000). A $5 \mathrm{~g}$ of the plant sample was weighed into the porcelain crucible and placed in the oven at temperature of $60-80{ }^{\circ} \mathrm{C}$ for $4 \mathrm{hrs}$. The dried sample was then weighed and the process was repeated until a constant weight was obtained. The weight lost signifies the moisture content and the percentage moisture content was calculated.

$\%$ Moisture Content $=\frac{M_{i}-M_{d}}{M_{i}} \times 100$

$M_{i}=$ Initial mass of plants sample

$M_{d}=$ Dried mass of plants sample

2.6Determination of plants ash content:The ash content of plant samples were determined following method described by Prometheus wiki, (1996). The plant dried sample was weighed in a porcelain crucible and the crucible was placed in muffle furnace at the temperatures of $550^{\circ} \mathrm{C}$ for $6 \mathrm{hrs}$. After ashing, the ashed plant sample was weighed and the percentage of ash content calculated as:

$\%$ Ash content $=\frac{M_{A S H}}{M_{D R Y}} \times 100$

$\mathrm{M}_{\mathrm{ASH}}=$ mass of the ashed sample

$\mathrm{M}_{\mathrm{DRY}}=$ mass of the dried sample

2.7 Soil moisture content determination:Soil samples moisture content were determined following method described by Hausenbuiller, (1975). The soil samples were oven dried at $105{ }^{\circ} \mathrm{C}$ for $24 \mathrm{hrs}$ cooled in a desiccator and re-weighed. The sample was returned to the oven at $105{ }^{\circ} \mathrm{C}$ for $3 \mathrm{hrs}$, cooled in a desiccator and reweighed. These processes of oven-drying, cooling and re-weighing continued until the weights of the soil samples were practically constant. The soil sampleswere then gently pulverized using mortar and pestle. The crucible was removed from the oven, cooled in a desiccator and the dried soil was weighed. The percentage moisture content was calculated as follows:

Percentage Moisture content $=\frac{M_{w}-M_{d}}{M_{d}} \times 100(3)$ 
$\mathrm{M}_{\mathrm{w}}=$ Mass of wet soil sample (wet weight - tare weight) (grams)

$M_{d}=$ Mass of dry soil sample (dry weight - tare weight) (grams)

2.8 Perchloric acid digestion of plant materials:Perchloric acid digestion ofplant samples were determined following method described by A.O.A.C., (1970). A $1 \mathrm{~g}$ of ground plant sample (oven dried at $60{ }^{\circ} \mathrm{C}$ ) was transferred into 50 $\mathrm{ml}$ Erlenmeyer flask which had been previously washed with acid and distilled water. A $2 \mathrm{ml} \mathrm{HClO}_{4}, 10 \mathrm{ml}$ conc. $\mathrm{HNO}_{3}$ and $2 \mathrm{ml}$ conc. $\mathrm{H}_{2} \mathrm{SO}_{4}$ were added under a fume hood to the plant sample. The mixture was shaken and heated gently from low to medium heat on a hot plate under a fume hood. The heating was continuous until dense white fumes appeared. Finally, it was heated strongly for half a minute (i.e. medium to high). The digested sample was allowed to cool, and then $20 \mathrm{ml}$ of distilled water was added. The diluted digest was boiled for $30 \mathrm{sec}$ at medium heat. The digest was cooled and filtered into $50 \mathrm{ml}$ Pyrex Standard flask. The filtrate was made to mark with distilled water and transferred into plastic vial for chloride determination which was done through Mohr titration method and $\mathrm{Pb}, \mathrm{Cd}, \mathrm{Zn}, \mathrm{Fe}, \mathrm{Ca}$, $\mathrm{Mg}$ were determined using ALPHA 4 Chem Tech Analytical model of Atomic Absorption Spectrometer (AAS).

2.9 Digestion of soil samples:Digestion of soil samples were determined following method described by Nieuwenhuize et al., (1991). The soil samples were air dried and passed through $2 \mathrm{~mm}$ sieve. A $5 \mathrm{~g}$ of the air dried sieved soil was weighed and digested with $20 \mathrm{ml}$ of aqua regia $\left(\mathrm{HCl} / \mathrm{HNO}_{3}, 3: 1\right)$ under fume hood, on a hot plate until a dense white fume appeared. Thedigest was cooled and $20 \mathrm{ml}$ of distilled water was added into the beaker, the diluted digest was then placed on hot plate and heated strongly. The digest was filtered into $100 \mathrm{ml}$ standard flask after cooling and the filtrate was made up to the mark of the standard flask. From the filtrate, $\mathrm{Pb}$, $\mathrm{Cd}, \mathrm{Zn}, \mathrm{Fe}, \mathrm{Ca}$, and $\mathrm{Mg}$ were determined using ALPHA 4 Chem Tech Analytical model of Atomic Absorption Spectrometer (AAS). Chloride was also determined using Mohr titration method.

2.10Determination of nitrate in plants:Nitrate in the plant samples were determined following method described by Cataldo et al., (1975). A $0.25 \mathrm{ml}$ of aliquot of extract of digestion was pipette into $50 \mathrm{ml}$ Erlenmeyer flask and mixed thoroughly with $0.8 \mathrm{ml}$ of $5 \%$ (w/v) salicylic acid$\mathrm{H}_{2} \mathrm{SO}_{4}$ reagent. After $20 \mathrm{~min}$ of mixture, $19 \mathrm{ml}$ of $2 \mathrm{~N}$ $\mathrm{NaOH}$ was added to raise the $\mathrm{pH}$ above 12 , the sample was then cooled to room temperature. The absorbance of this mixture was measured at $410 \mathrm{~nm}$.

2.11Determination of nitrate in soil sample:Nitrate in the soil samples were determined following method described by Greweling and Peech, (1975). Extraction: A $5 \mathrm{~g}$ of the soil samples was weighed and transfer into the $100 \mathrm{~mL}$ conical flask. Then $0.25 \mathrm{~g}$ activated carbon and $20 \mathrm{ml}$ of extracting solution were added to the soil sample in the conical flask. The extracting solution was prepared by adding together $100 \mathrm{~g} \mathrm{CH}_{3} \mathrm{COONa}$ and $30 \mathrm{ml}$ of $99.58 \%$ $\mathrm{CH}_{3} \mathrm{COOH}$ in $1000 \mathrm{ml}$ standard flask. The solution was made up to mark with deionized water. The soil sample mixture was shaken for $1 \mathrm{~min}$ and filtered.

A $1 \mathrm{ml}$ of the aliquot of the soil extract was transferred into a vial and $0.5 \mathrm{ml}$ of brucine reagent was added into the aliquot and $2 \mathrm{ml} \mathrm{H}_{2} \mathrm{SO}_{4}$ was added rapidly into the conical flask and mixed carefully for $30 \mathrm{sec}$. The sample was left to stand for $5 \mathrm{~min}$ before absorbance of the sample was taken at $470 \mathrm{~nm}$ using spectrophotometer.

A 100 ppm standard $\mathrm{NO}_{3}-\mathrm{N}$ was prepared from $\mathrm{KNO}_{3}$ salt as the stock solution and five different concentrations ( $0-$ $2 \mathrm{ppm}$ ) were prepared from the stock solution through serial dilution. A $1 \mathrm{ml}$ of each known concentration standards prepared was carried through the same procedure with the soil extracts.

2.12Phosphate determination in plant samples:Phosphate in the plant samples were determined following method described by Murphyand Riley, (1962). Working solution (prepared fresh daily) - A $12.7 \mathrm{~g}$ ammonium molybdate was dissolved in $250 \mathrm{ml}$ of distilled water, then $0.291 \mathrm{~g}$ antimony potassium tartarate was dissolved in $100 \mathrm{ml}$ of distilled water. Ascorbic acid was also prepared by dissolving $2.625 \mathrm{~g}$ in distilled water and diluting to $500 \mathrm{ml}$. The three reagents were added into $1000 \mathrm{ml}$ of $5 \mathrm{~N} \mathrm{H}_{2} \mathrm{SO}_{4}$, The solution was mixed thoroughly and make to $2000 \mathrm{ml}$ with distilled water and stored in a Pyrex glass bottle in a dark compartment.

A $1 \mathrm{ml}$ of the digested samples that were digested via wet oxidation was quantitatively transferred into 100 mlvolumetric flasks and dilute with distilled water. Using a dilutor-dispenser, the diluted samples and the standards prepared were treated in 1:100 with the working solution. Colour was allowed to develop for at least 30 min before reading. The absorbance of each sample was taken at $660 \mathrm{~nm}$ with a spectrophotometer.

2.13Determination of phosphate in soil samples:Phosphate in the soil samples were determined following method described by Samira et al., (2009). Extraction: A $50 \mathrm{~g}$ of the soil samples was weighed and transferred into $250 \mathrm{ml}$ conical flask and shaken with exactly $50 \mathrm{ml}$ of $\mathrm{NaHCO}_{3}$ at $\mathrm{pH}$ 8.5. The samples were shaken on an orbital mechanical shaker for $10 \mathrm{~min}$.

A $10 \mathrm{ml}$ aliquot of the extract was transferred into a $50 \mathrm{ml}$ conical flask, $10 \mathrm{ml}$ of the colour developing reagent was added, stirred and allowed to stand for $15 \mathrm{~min}$. The absorbance wasmeasured using UV/ Visible Spectrophotometer and glass cells at $880 \mathrm{~nm}$. Standard 
calibration curve was prepared from the standard solutions of $\mathrm{KH}_{2} \mathrm{PO}_{4}$.

\section{RESULTS AND DISCUSSION}

The moisture content of the soil (Table 1) decreases down the soil profile in all stations and it influenced the rate at which ionic species in the soil are been percolated down the soil. The result of plant moisture contents (Table 2) are low and it affects the availability of the ionic species (Emmanuel and Folashade, 2011) because amaranth accumulated all the ionic species studied better than others in the case of iron and nitrate. The ash content of the plant samples were also in agreement with literatures (Aletor et al., 2002;Anhwange et al., 2009).

Nitrate concentrations increase down the soil profile in all stations (Table 1), and the solubility of nitrate may have attributed to its ease of percolation (Aletor et al., 2002). Therefore, the fraction, $30-45 \mathrm{~cm}$ had the highest of nitrates ions. The nitrate level in an increasing order among the soil fractions are $0-15 \mathrm{~cm}<$ $15-30 \mathrm{~cm}<30-45 \mathrm{~cm}$.

From Table 2 the concentrations of nitrate in the five plants samples studied were $1.25,3.25,0.75,0.25$, $0.05 \mathrm{mg} / \mathrm{l}$ in A. hybridus, T. diversifolia, I. batatas, $C$. agentea, M. escunlentarespectively. These values are low when compared with the nitrate concentrations of some edible wild plants earlier reported (Ugur and Selima, 2011 ) in which plants with least nitrate concentration had $43.42 \mathrm{mg} / \mathrm{l}$. The low result here may be due to nitrate concentration in the soil samples. This implies that the concentration of the soil at the depth of the root determines the concentration of the ionic specie in the plants. Both the plants and the soil samples did not exceed the safe limit of intake of nitrate, which is $45 \mathrm{mg} / \mathrm{l}$ according to WHO (WHO, 1987).

Phosphate concentration at the soil surface layer (Table 1) is higher than its concentration at the depth of 15-30 and $30-45 \mathrm{~cm}$ in station 2 and station 3 . In station 1 , the concentration of phosphate is higher at depth of $15-30 \mathrm{~cm}$. Phosphate concentration in the dump site soil are attributed to the decaying bone ash which is slowly released into the soil and this accounted for low concentration of the phosphate in the soil (Phillip, 2004). The concentration of phosphate in the five plants samples were $0.5,1.45,0.4,1.8,0.95 \mathrm{mg} / \mathrm{l}$ for I. batatas, $T$. diversifolia, $M$. escunlenta, A. hybridus, $C$. agentearespectively. Comparing the results of a similar research on three of these plants from where the concentration of $\mathrm{PO}_{4}{ }^{3-}$ in C. agentea,A. hybridus and $I$. batatas are $0.29,0.95$ and $0.62 \mathrm{mg} / \mathrm{l}$ respectively (Orhue et al., 2010; Decuypere, 2000), the concentration of phosphate in the plant samples is relatively high in $A$. hybridus and low in I. batatas grown on the dumpsite.
The content of chloride $(\mathrm{mg} / \mathrm{l})$ in the soil (Table 1) followed the same progression in all stations; the depth of $15-30 \mathrm{~cm}$ has the highest value of chloride while the chloride content in the five plants samples (Table 2) are 17.35, 12.18, 10.89, 7.94, $5.54 \mathrm{mg} / \mathrm{l}$ in A. hybridus, $I$. batatas, $\quad$. diversifolia, $M$. escunlenta, $C$. agentearespectively. It also revealed that $A$. hybridusbioaccumulated chloride most among all the plant samples studied.

From Table 1, the highest concentration of calcium was found in station 2 with $(15-30 \mathrm{~cm})$ and $(30-$ $45 \mathrm{~cm}$ ) depth having 832.58 and $947.54 \mathrm{mg} / 1$ which are $41 \%$ and $47 \%$ of total calcium respectively. The similar results in the five plants samples studied are 577.12, 501.08, 496.07, 296.51, $173.54 \mathrm{mg} / 1$ in A. hybridus, $C$. agentea, $T$. diversifolia, $I$. batatas, $M$. escunlentarespectively. This shows that the concentration of calcium in the plants grown on the dumpsite is relatively high, when compared to calcium levels in two of these plants, A. hybridus (276 mg/l) and I. batatas (43 $\mathrm{mg} / \mathrm{l}$ ) from a similar research (Decuypere, 2000).

The percentage concentration of magnesium in the soil varied among the three stations and depths. Station 1 has the highest concentration $(23.34 \mathrm{mg} / \mathrm{l})$ in the depth of $15-$ $30 \mathrm{~cm}$, station 2 has the concentration of magnesium increase down the soil profile and station 3 has the least concentration of magnesium $(24.93 \mathrm{mg} / \mathrm{l})$ at the depth of $15-30 \mathrm{~cm}$. It was also observed that the concentrations of magnesium in the five plants samples are 324.25, 272.08, 139.25, 136.53, $61.85 \mathrm{mg} / \mathrm{l}$ in A. hybridus, C. agentea, T. diversifolia, I. batatas, M. escunlentarespectively. A far lower value has been reported for A. hybridus and $I$. batatas having values of $73 \mathrm{mg} / \mathrm{l}$ and $48 \mathrm{mg} / \mathrm{l}$ respectively (Decuypere, 2000). This shows that the concentration of magnesium in the studied plant samples is very high.

Generally, iron was the most abundant heavy metal in the soil among the heavy metals studied. The heavy metals available in the soil fell within the normal range of heavy metals in the soil except iron whose concentration in all station exceed WHO normal range $(425 \mathrm{mg} / \mathrm{kg})$ in soil.

From Table 1, the concentrations of the various metals in station 1 for $0-15 \mathrm{~cm}$ depth, $\mathrm{Fe}=1077.5, \mathrm{Zn}=$ 1.732, $\mathrm{Cd}=0.00, \mathrm{~Pb}=0.48 \mathrm{mg} / \mathrm{l}$, for depth of $15-30 \mathrm{~cm}$, $\mathrm{Fe}=1072.53, \mathrm{Zn}=4.692, \mathrm{Cd}=0.00, \mathrm{~Pb}=1.11 \mathrm{mg} / \mathrm{l}$. The availability of some heavy metals was known to decrease with rising $\mathrm{pH}$ of the soil (Fargasova, 1994). The $\mathrm{pH}$ of the soils in station 1 are 7.5, 6.7, 6.8 in the depth of (0-15), (15-30), (30-45) cm respectively.

The concentration of heavy metals in the five plants samples studied is presented in Table 2 but $\mathrm{Cd}$ and $\mathrm{Pb}$ were not detected in all the plants samples studied. This may be due partly to below detection of AAS used, low concentration levels in the soil, or absence in the 
studied area. In comparison to an earlier research (Anhwange et al., 2009), where it was reported that the concentration of $\mathrm{Fe}, \mathrm{Zn}, \mathrm{Cd}$ and $\mathrm{Pb}$ in A. hybriduswere $1.28,0.52,0.15$ and $0.06 \mathrm{ppm}$ respectively, the concentrations obtained in this study showed higher bioaccumulation (Table 2) by similar plants. This may be attributed to high metal content in the soil and/or maturity status of the plants. It was revealed that all the plant samples used are poor accumulator of $\mathrm{Cd}$ and $\mathrm{Pb}$. The normal concentration of $\mathrm{Fe}$ and $\mathrm{Zn}$ in A. hybridus and I.batatasare $2.98,1.16$ and $1.87,0.62 \mathrm{mg} / \mathrm{l}$ respectively, this show that the concentration of iron in the plants are generally high while the concentration of $\mathrm{Zn}$ relativelynormal (Decuypere, 2000). The mean concentrations of heavy metals in stations 1,2 and 3 (Table 1) are within the normal range in the soil except iron.

\section{CONCLUSION}

This study revealed that plants grown on contaminated area have the high risk of bioaccumulation of heavy metal beyond the permissible limits. The concentrations of calcium and magnesium in the plants were relatively high and are linked to high concentrations of the metals in the soil, especially in station 2 . The concentrations of the anions are within the normal acceptable range except phosphate concentration in A. hybridus.

This research also shows that plants grown on the abandoned dumpsites of Asa Dam Road have heavy metals within the permissible limit of WHO/FAO (World Health organization/ Food and Agriculture Organization), EU (Economy Union) and EC (Economic Commission). Amaranthushybridushyper-accumulated heavy metals and anions most among other plants. This study shows that the availability of heavy metals in the soil depends on the quality and quantity of wastes heaped up at that point. None of the plants studied is a good hyper-accumulator of $\mathrm{Cd}$ and $\mathrm{Pb}$, and the possibly low concentrations of $\mathrm{Cd}$ and $\mathrm{Pb}$ in the soil also affected the result.

Soil condition such as $\mathrm{pH}$, moisture content, porosity, presence of electron acceptor all affects the soil and the type of plant to use for bioremediation also depends on the targeted pollutants. The plants grown on Asa Dam Road abandoned dump sites are not toxic to the body because of the concurrent low concentration of heavy metals available in the soil.

Amaranthushybridusand Celosia agenteaare used as consumable vegetables and the consumption will raise bio-accumulation of heavy metals in the body. SinceAmaranthushybridusand Celosia agenteaare meant for food, they should not be planted on heavy metals contaminated soil.Tithoniadiversifoliais a mild hyperaccumulator and it is used as herb. So heavy metals will be release during extraction of the plant juice and long accumulation of the heavy metals in the body can cause problems that are more chronic to human. Therefore, Tithoniadiversifoliashould be planted on the land with either no or low concentration of toxic metals. ManihotescunlentaandIpomeabatatasare very low in bioaccumulation of heavy metals except thatManihotescunlentahyper-accumulated iron most. Hence they are poor hyper-accumulator of the heavy metals studied. Most of the heavy metals in a tuber crop accumulate at the tuber and this cause its low concentration in the leaves.

\section{REFERENCES}

Abdus-Salam, N. 2009.Assessment of heavy metals pollution in dumpsites in Ilorin metropolis.Ethiopian Journalof Environmental Studies \& Management, 2(2): 92-99.

Ajaz, H.M.R., A.V.Thirumalai, K.R.Narayananb and H.M.I. Zahir. 2010. Bioremediation of heavy metal contaminated soil by the Exigobacteriumand accumulation of $\mathrm{Cd}, \mathrm{Ni}, \mathrm{Zn}$ and $\mathrm{Cu}$ from soil environment. International Journal of Biological Technology, 1(2):94-101.

Aletor, O., A.A. Oshodi and K.O. Ipinmoroti. 2002. Chemical composition of common leafy vegetables and functional properties of their leaf protein concentrate. Food Chemistry, 78: 63-68.

Anhwange, B.A., J.A. Kagbu, E.B. Agbaji and C.E.Gimba.2009. Trace metal contents of some common vegetables grown on irrigated farms along the banks of river benue within Makurdi metropolis.Electronic Journal of Environmental, Agricultural and Food Chemistry,8(11): 1150-1155.

Association of Official Analytical Chemists (A.O.A.C), (1970).Official methods of Analysis, Ed, 11, Washington D.C.

Cataldo, D.A., M. Haroon, L.E. Schrader and V.L. Youngs. 1975. Rapid colorimetric determination of nitrate in plant tissues by nitration of salicylic acid. Communications in Soil Science and Plant Analysis, 6(1): 71-80.

Decuypere, J.D. 2002. Mineral and nutrients charts. www. Healthalternatives.com/2000. minerals-nutririonchat.html, Retrieved 09/07/2012.

Douglas, K. 2013. Chapter 11: Solid waste. Maiden code of ordiniances, Ordiniance No 16-92, pp. $1-7$.

Duruibe, J.O., M.O.C. Ogwuegbu and J.N. Egwurugwu. 2007. Heavy metal pollution and human biotoxic effects. International Journal of Physical Sciences, 2(5): 112-118. Emmanuel, I.A. and O.O. Folashade. 2011. Chemical composition and functional properties of leaf protein concentrates of Amaranthus Hybridus and 
TelfairiaOccidentalis.Agriculture and Biology Journal of North America, 2(3): 499-511.

Fargasova, A. 1994. Effect of $\mathrm{Pb}, \mathrm{Cd}, \mathrm{Hg}$, As and $\mathrm{Cr}$ on germination and root growth of Sinapis alba seeds. Bulletinof Environmental Contamination \& Toxicology, 52(3): 452-456.

Gardea-Torresdey, J.L., S. Arteage, K.J. Tiemann, R. Chianelli, N. Pingitore and W.Mackay. 2001. Absorption of Copper (II) by creosote bush (L. Tridentata): Use of atomic and X-Ray absorption spectroscopy. Environmental Toxicology and Chemistry,2(11):25722579.

Greweling, T. and M. Peech. 1965. Chemical soil tests. Cornell UniversityAgriculturalExperiment Station, Bulletin 960.

Hausenbuiller, R.L. 1975. Soil Science Principles and Practice, 4th printing p. 90.

Murphy, J. and J.P. Riley. 1962. A modified single solution method for the determination of phosphate in natural waters. AnalyticaChimicaActa, 27:31-36.

Nieuwenhuize, J., C. Poley-Vos, H.V. Adrianus and V. Wouter. 1991. Comparison of microwave and conventional extraction techniques for the determination of metals in soil, sediment and sludge samples by Atomic Spectrometry. Analyst, 116: 347-351.

Nwoko, C.O. and L.Mgbeahuruike. 2011. Heavy metal contamination of ready-to-use herbal remedies in South Eastern Nigeria.Pakistan Journal of Nutrition, 10(10): 959-964.

Ogundiran, M.O. and O. Osibanjo. 2008. Heavy metal concentrations in soils and accumulation in plants growing in a deserted slag dumpsite in Nigeria. African Journal of Biotechnology, 7(17): 3053-3060.

Opaluwa, O.D., M.O. Aremu, L.O. Ogbo, K.A. Abiola, I.E. Odiba, M.M. Abubakar and N.O. Nweze. 2012. Heavy metal concentrations in soils, plant leaves and crops grown around dump sites in Lafia Metropolis, Nasarawa State, Nigeria. Advances in Applied Science Research, 2: 780-784.

Orhue, E.R. and S. Inneh. 2010. Uptake of lead by Celosia Argenteain an Ultisol. Research Journal of Agriculture andBiological Sciences, 6(2): 103-107.

Phillip, M. 2004. Nitrate, Use of Phosphate Salts, Advanced Chemistry, Cambridge University. pp. 612, $622-623$.

Prometheus Wiki. 1996. Protocol in ecological and environmental plant physiology, determination of ash content and ash alkalinity, CSIRO (Commonwealth Scientific and Industrial Research Organisation), Retrieved from http://www.prometheuswiki.publish. csiro.au/tiki-ndex.php?page
Salami, N. and F.A. Adekola. 2002. A study of sorption of cadmium by goethite in aqueous solution. Bulletinof the Chemical SocietyofEthiopianJournal,16(1): 1-7.

Samira, A.B., M. Hawaa, S.E. Faiza, and F.A. Fatma. 2009. Determination of available nitrate, phosphate and sulfate in soil samples. International Journal of Pharmaceutical Sciences and Research, 1(3): 598-604.

Schofield, R.K. and A.W. Taylor. 1955. The measurement of soil pH.Soil Science Society Proceedings 19: 164-167. Scott, C.D. 1992. Removal of dissolved metals by plant tissues. Biotechnology and Bioenineering, 39: 1064 1068.

UCDAVIS (University of California, DAVIS).(2000).Plant sampling, preparation, and drying recommendation. College of Agricultural and Environmental

Sciences,Retrievedfromanlab.ucdavis.edu/sampling/plantsampling-and-preparation.

Ugur, C. and K. Selima. 2011. Nitrate, moisture and ash contents of edible wild plants. Journalof Cell and Plant Science, 2(1): 1-5.

WHO (World Health Organisation). 1987. Air quality guidelines for Europe. WHO Regional Publications, European Series No. 23.World Health Organization officer for Europe, Copenhagen. 


\section{LIST OF TABLES}

The comparative analytical results of the five plant samples and nine soil samples collected from the abandoned Asa dam road dump site are presented in Table 1 -3 below.

Table 1: Physicochemical analysis of soil samples collected from the abandoned Asa Dam Road dump site

\begin{tabular}{|c|c|c|c|c|c|c|c|c|c|c|c|c|}
\hline & $\begin{array}{c}\text { Sampli } \\
\text { ng } \\
\text { Depth } \\
(\mathrm{cm})\end{array}$ & $\begin{array}{c}\mathrm{Ca} \\
(\mathrm{mg} / \mathrm{L})\end{array}$ & $\begin{array}{c}\mathrm{Mg} \\
(\mathrm{mg} / \mathrm{L} \\
)\end{array}$ & $\begin{array}{c}\mathrm{Fe} \\
(\mathrm{mg} / \mathrm{L} \\
)\end{array}$ & $\begin{array}{c}\mathrm{Zn} \\
(\mathrm{mg} / \mathrm{L} \\
)\end{array}$ & $\begin{array}{c}\mathrm{Cd} \\
(\mathrm{mg} / \mathrm{L})\end{array}$ & $\begin{array}{c}\mathrm{Pb} \\
(\mathrm{mg} / \mathrm{L} \\
)\end{array}$ & $\begin{array}{c}\mathrm{NO}_{3}{ }^{-} \\
(\mathrm{mg} / \mathrm{L} \\
)\end{array}$ & $\begin{array}{c}\mathrm{PO}_{4}{ }^{3-} \\
(\mathrm{mg} / \mathrm{L} \\
)\end{array}$ & $\begin{array}{l}\mathrm{Cl}^{-} \\
(\mathrm{mg})\end{array}$ & $\begin{array}{c}\% \\
\text { Moistu } \\
\text { re } \\
\text { content }\end{array}$ & $\mathrm{pH}$ \\
\hline \multirow{4}{*}{ Station 1} & $0-15$ & 1.16 & 14.46 & $\begin{array}{c}1077 . \\
5\end{array}$ & 1.732 & ND & 0.48 & 0.775 & 0.74 & 54.64 & 9.57 & 7.5 \\
\hline & $15-30$ & 90.64 & 23.34 & $\begin{array}{c}1072 . \\
5\end{array}$ & 4.692 & ND & 1.11 & 0.875 & 0.745 & 69.23 & 4.69 & 6.7 \\
\hline & $30-45$ & 7.01 & 14.08 & $\begin{array}{c}845.0 \\
1\end{array}$ & 1.303 & ND & 0.35 & 1.575 & 0.58 & 30.27 & 4.55 & 6.8 \\
\hline & $\begin{array}{c}\text { Averag } \\
\mathrm{e}\end{array}$ & 32.93 & 17.29 & 998.3 & 2.576 & ND & 0.65 & 1.075 & 0.69 & 51.38 & 6.27 & 7.0 \\
\hline \multirow{4}{*}{ Station 2} & $0-15$ & 832.58 & 53.35 & $\begin{array}{c}717.5 \\
2\end{array}$ & $\begin{array}{c}33.45 \\
1\end{array}$ & ND & 3.32 & 1.05 & 1.38 & 91 & 17.53 & 7.3 \\
\hline & $15-30$ & 947.54 & 82.11 & $\begin{array}{c}1117 . \\
5\end{array}$ & $\begin{array}{c}73.11 \\
2\end{array}$ & 0.03 & 3.65 & 1.3 & 0.44 & $\begin{array}{c}148.2 \\
3\end{array}$ & 14.66 & 7.1 \\
\hline & $30-45$ & 55.66 & 85.49 & $\begin{array}{c}1425 . \\
1\end{array}$ & $\begin{array}{c}82.53 \\
4\end{array}$ & 0.044 & 2.45 & 1.58 & 1.1 & 27.51 & 14.45 & 7.4 \\
\hline & $\begin{array}{c}\text { Averag } \\
\mathrm{e}\end{array}$ & 611.93 & 73.65 & $\begin{array}{c}1086 . \\
71\end{array}$ & 63.03 & 0.037 & 3.14 & 1.31 & 0.97 & 88.91 & 15.55 & 7.3 \\
\hline \multirow{4}{*}{ Station 3} & $0-15$ & 35.82 & 95.04 & $\begin{array}{c}1402 . \\
5\end{array}$ & $\begin{array}{c}61.49 \\
1\end{array}$ & 0.065 & 0.64 & 1.18 & 1.1 & 39.87 & 18.58 & 6.9 \\
\hline & $15-30$ & 24.93 & 83.15 & $\begin{array}{c}1437 . \\
6\end{array}$ & $\begin{array}{c}53.85 \\
3\end{array}$ & 0.05 & 1.78 & 1.55 & 0.865 & 44.67 & 12.99 & 7.1 \\
\hline & $30-45$ & 27.84 & 96.35 & $\begin{array}{c}1325 . \\
2\end{array}$ & $\begin{array}{c}36.15 \\
6\end{array}$ & 2.416 & ND & 1.75 & 0.78 & 10.52 & 12.5 & 7.2 \\
\hline & $\begin{array}{c}\text { Averag } \\
\mathrm{e}\end{array}$ & 29.53 & 91.51 & $\begin{array}{c}1388 . \\
43\end{array}$ & 50.5 & 0.84 & 1.21 & 1.49 & 0.915 & 31.69 & 14.69 & 7.1 \\
\hline
\end{tabular}

\section{ND: Not Detected}

Station 1: site nearest to Asa Dam Road

Station 2: site at the center of Asa Dam Road dump site

Station 3: site towards the end of the dump site

Table.2: Some physicochemical analysis of the plant samples collected from the abandoned Asa Dam Road dump site

\begin{tabular}{|c|c|c|c|c|c|c|c|c|c|c|c|}
\hline SAMPLES & $\begin{array}{c}\mathrm{Ca} \\
(\mathrm{mg} / \mathrm{L})\end{array}$ & $\begin{array}{c}\mathrm{Mg} \\
(\mathrm{mg} / \mathrm{L})\end{array}$ & $\begin{array}{c}\mathrm{Fe} \\
(\mathrm{mg} / \mathrm{L})\end{array}$ & $\begin{array}{c}\mathrm{Zn} \\
(\mathrm{mg} / \mathrm{L})\end{array}$ & $\begin{array}{c}\mathrm{Cd} \\
(\mathrm{mg} / \mathrm{L})\end{array}$ & $\begin{array}{c}\mathrm{Pb} \\
(\mathrm{mg} / \mathrm{L})\end{array}$ & $\begin{array}{l}\mathrm{NO}_{3}{ }^{-} \\
(\mathrm{mg} / \mathrm{L})\end{array}$ & $\begin{array}{l}\mathrm{PO}_{4}{ }^{3-} \\
(\mathrm{mg} / \mathrm{L})\end{array}$ & $\begin{array}{c}\mathrm{Cl}^{-} \\
(\mathrm{mg} / \mathrm{L})\end{array}$ & $\begin{array}{c}\% \\
\text { Moisture } \\
\text { content }\end{array}$ & $\begin{array}{l}\% \text { Ash } \\
\text { content }\end{array}$ \\
\hline Ipomeabatatas & 296.51 & 136.53 & 7.89 & 0.695 & ND & ND & 0.75 & 0.5 & 12.18 & 13.78 & 21 \\
\hline Tithoniadiversifolia & 496.07 & 139.25 & 8.81 & 0.843 & ND & ND & 3.25 & 1.45 & 10.89 & 7.87 & 16.67 \\
\hline Amaranthushybridus & 577.12 & 324.25 & 5.75 & 1.559 & ND & ND & 1.25 & 1.8 & 17.35 & 3.75 & 11.89 \\
\hline Celosia agentea & 501.08 & 272.08 & 9.19 & 1.361 & ND & ND & 0.25 & 0.95 & 5.54 & 5.51 & 12.71 \\
\hline Manihotescunlenta & 173.54 & 61.85 & 10.45 & 0.748 & ND & ND & 0.05 & 0.4 & 7.94 & 3.94 & 6.35 \\
\hline Average & 408.86 & 186.79 & 8.42 & 1.0412 & ND & ND & 1.11 & 1.02 & 10.78 & 6.97 & 13.72 \\
\hline
\end{tabular}

ND: Not Detected 
Table.4: WHO/FAO safe limit for heavy metals uptake in plant and soil samples (Opaluwa et al., 2012).

\begin{tabular}{ccccc}
\hline Metals $(\mathrm{mg} / \mathrm{kg})$ & WHO/FAO & EC/CODEX & $\begin{array}{c}\text { Normal Range in } \\
\text { Plant }\end{array}$ & $\begin{array}{c}\text { Normal Range in } \\
\text { soil }\end{array}$ \\
\hline $\mathrm{Cd}$ & 1 & 0.2 & $<2.4$ & 3 \\
$\mathrm{~Pb}$ & 2 & 0.3 & $0.50-30$ & $2-200$ \\
$\mathrm{Zn}$ & 60 & $<50$ & $20-100$ & $20-300$ \\
$\mathrm{Fe}$ & 48 & - & $400-500$ & 425 \\
\hline
\end{tabular}

